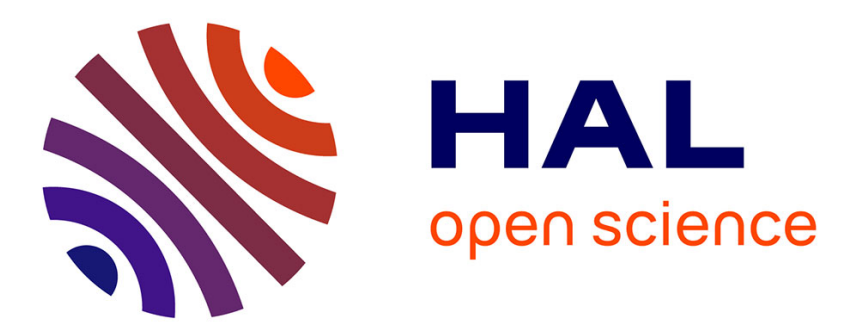

\title{
Effect of long-acting $\beta$-agonist on bronchodilator response in children with asthma
}

\author{
Jessica Taytard, Camille Aupiais, Sophie Jovien, Jessica Assouline Kabla, \\ Noémie Haziot, Marilyn Fuger, Corinne Alberti, Nicole Beydon
}

\section{To cite this version:}

Jessica Taytard, Camille Aupiais, Sophie Jovien, Jessica Assouline Kabla, Noémie Haziot, et al.. Effect of long-acting $\beta$-agonist on bronchodilator response in children with asthma. European Respiratory Journal, 2020, 56 (3), pp.1902010. 10.1183/13993003.02010-2019 . hal-03269484

\section{HAL Id: hal-03269484 https://hal.sorbonne-universite.fr/hal-03269484}

Submitted on 24 Jun 2021

HAL is a multi-disciplinary open access archive for the deposit and dissemination of scientific research documents, whether they are published or not. The documents may come from teaching and research institutions in France or abroad, or from public or private research centers.
L'archive ouverte pluridisciplinaire HAL, est destinée au dépôt et à la diffusion de documents scientifiques de niveau recherche, publiés ou non, émanant des établissements d'enseignement et de recherche français ou étrangers, des laboratoires publics ou privés. 


\section{Effect of Long-Acting Beta-Agonist on bronchodilator response in asthmatic children}

Jessica Taytard ${ }^{1,2}$, Camille Aupiais ${ }^{3,5}$, Sophie Jovien ${ }^{4}$, Jessica Assouline Kabla ${ }^{4}$, Noémie Haziot ${ }^{4}$, Marilyn Fuger ${ }^{4}$, Corinne Alberti ${ }^{3,5,6}$, Nicole Beydon ${ }^{2,4}$

${ }^{1}$ AP-HP, Hôpital Trousseau, Pediatric Pulmonary Department, Paris, France

${ }^{2}$ Sorbonne Université, INSERM U938 Centre de Recherche Saint Antoine, Paris, France

${ }^{3}$ AP-HP, Hôpital Robert Debré, Unit of Clinical Epidemiology, Paris, France

${ }^{4}$ AP-HP, Hôpital Trousseau, Pediatric Pulmonary Function Test department, Paris, France

${ }^{5}$ Université Paris Diderot, Sorbonne Paris-Cité, INSERM U1123, Paris, France

${ }^{6}$ INSERM CIC-EC 1426, Paris, France

\section{Corresponding author:}

Correspondance to $\mathrm{Dr}$ Nicole Beydon, Unité Fonctionnelle de Physiologie-Explorations Fonctionnelles Respiratoires (EFR), Hôpital Armand-Trousseau 26 Avenue du Docteur Arnold Netter, 75571 Paris Cedex 12, France. Phone : +33 1447363 32, Fax +33 1447363 36, E-mail: nicole.beydon@trs.aphp.fr

"take home" message: If Long-Acting Beta 2-Agonist are not withhold before pulmonary function test in asthmatic children, its effect on baseline function will be evaluated, but significant $\mathrm{FEV}_{1}$ reversibility will occur independently of LABA inhalation 


\section{To the editor}

Spirometry is the most common pulmonary function test (PFT) used to follow asthmatic patients. It is recommended to withhold Short-Acting Beta 2-Agonists (SABA) a few hours before PFTing, and to withheld Long-Acting Beta 2-Agonists (LABA) for diagnosis purpose but not for the assessment of response to a current treatment [1]. In asthmatic children, the addition of LABA to inhaled corticosteroids (ICS) has no clear clinical benefit but it has proved to improve baseline Forced Expiratory Volume in 1 second $\left(\mathrm{FEV}_{1}\right)[2]$. The maximal increase in $\mathrm{FEV}_{1}$ after a single dose of formoterol was measured 3 hours after administration but the remaining effect after 12 hours would depended on the inhaled dose [3]. Finally, $25 \mu \mathrm{g}$ or $50 \mu \mathrm{g}$ of Salmeterol inhaled at 10 p.m. resulted in higher baseline pulmonary function and decrease in exercise induced bronchoconstriction 10 and 12 hours later [4]. In routine practice, children are tested with various delays since last LABA inhalation, but LABA is usually inhaled on the morning of the test $(<12 \mathrm{~h}$ before), in the evening the previous day $(>12 \mathrm{~h})$ or on the morning the previous day or before $(>24 \mathrm{~h})$. It is thought that children with the most recent inhalation should have the best pulmonary function and the lowest reversibility, but the latest issue has not been studied.

To study the effect of the delay since the last dose of LABA on the BDR, we prospectively and consecutively included, from May 2015 to April 2016, children 6 to 18 years of age, referred for PFT from the outpatient clinic of our tertiary paediatric hospital with typical asthma treated with an association of ICS and LABA.

Exclusion criteria were 1) SABA inhaled $<8$ hours before PFT; 2) other chronic diseases potentially affecting PFT results; 3 ) moderate ( $\geq$ two days of rescue bronchodilator) or severe ( $\geq$ three days of oral corticosteroids) asthma exacerbation [5] within the last 7 or 15 days, respectively, 
or current acute asthma symptoms; 4) patient unable to perform spirometry. Parents and patients over 8 years of age gave informed consent for the study, which was approved by the Institutional Review Board of the French learned society for respiratory medicine -Société de Pneumologie de Langue Française- (CEPRO 2015-017).

Anthropometric and clinical characteristics of asthma disease were recorded, including environmental tobacco smoke exposure (ETS), history of hospitalization for asthma flare-up, asthma exacerbations within the last three months, asthma symptom control according to the Global Initiative for Asthma (www.ginasthma.org). The child's ability to use his/her inhaler (including a demonstration using an empty disposal and questions on how he/she knew when it was empty) was determined using a standardized questionnaire. The child then performed baseline and post-BD (Salbutamol $400 \mu \mathrm{g}$ metered-dose inhaler in a spacer) spirometry (BodyBox, Medisoft, Sorinnes, Belgium) according to international guidelines [6].

The lower normal limit (LLN) for spirometry indices was set at -1.64 z-score [7] and FEV 1 reversibility was significant if $\geq 12 \%$ predicted without absolute change criterion as children $<10$ years were included [8]. Quantitative variables were compared using the Wilcoxon-Mann-Whitney test. The relationships between the delay since the last inhalation of LABA and baseline obstruction or $\mathrm{FEV}_{1}$ reversibility were studied using Cochran-Armitage test for trend. Univariate analyses between $\mathrm{FEV}_{1}$ reversibility and clinical characteristics, the type of inhaler used, the last dose of LABA (full dose [ie $12 \mu \mathrm{g}$ for Formoterol, $50 \mu \mathrm{g}$ for Salmeterol] or half dose), baseline $\mathrm{FEV}_{1}$ and $\mathrm{FEV}_{1}$ to Forced Vital Capacity (FVC) ratio were performed. Significant covariates at a $20 \%$ threshold were retained for the final multivariate model. The $P$-value confirmed a statistical relationship when $<0.05$ (two-sided). All statistical analysis was performed with SAS software (version 9.4, SAS Institute Inc., Cary, North Carolina, USA). 
We enrolled 267 patients, and secondarily excluded 7 children with unclear delay since last inhalation of LABA. 260 children (median [Q1;Q3] age 12.2 [9.6;14.9] years, 163 boys) were included in the three groups of analysis according to last LABA inhalation $(<12 \mathrm{~h}, \mathrm{n}=126 ; 12-24 \mathrm{~h}$, $\mathrm{n}=88$ and $>24 \mathrm{~h}, \mathrm{n}=46)$. Children were mostly Caucasian $(67.7 \%)$ and African-Caribbean (19.2\%). Frequencies of ETS (25.1\%), history of hospitalization (39.8\%), moderate or severe asthma exacerbations in the previous three months (37.8\%), and use of antileukotriene medication (39.5\%) were similar across groups. During the previous month, asthma was well, partly or not controlled in $84.9 \%, 12.0 \%$ and $3.1 \%$ of cases, respectively. A third of children were prescribed a Turbuhaler device $(n=85)$, half had a Diskus $(n=131)$ and a sixth a metered dose inhaler $(n=44)$. The children demonstrated a correct use of their devices in $85.4 \%$ of cases. The last dose of LABA taken before PFT was equally full dose (52.1\%) or half dose $(47.9 \%)$.

The baseline and post-BD PFT results across the three groups are shown in Table 1. The logistic regression including $\mathrm{FEV}_{1}$ reversibility as the dependent variable showed significant independent relationships with full dose of LABA inhaled (OR [95\% IC]: 0.24 [0.08;0.77]; $P=0.02$ ), baseline $\mathrm{FEV}_{1}>\mathrm{LLN}(\mathrm{OR}[95 \% \mathrm{IC}]: 0.14$ [0.04;0.53]; $P=0.003)$ and $\mathrm{FEV}_{1} / \mathrm{FCV}>\mathrm{LLN}$ (OR [95\%IC]: 0.24 $[0.08 ; 0.75] ; P=0.01)$. In contrast, there was no relationship between the delay since last dose of LABA and significant reversibility (12-24h OR [95\%IC]: $0.54[0.13 ; 2.16] ; P=0.38 ;>24 \mathrm{~h}$ OR [95\% $\mathrm{IC}]: 1.38[0.41 ; 4.64] ; P=0.60)$. It is to be noted that there was no interaction between baseline $\mathrm{FEV}_{1}$ and $\mathrm{FEV}_{1} / \mathrm{FVC}(P=0.11)$, and that the molecule inhaled did not influenced the results.

The children with an inhalation technique judged as correct were younger than those with an incorrect technique $(11.8[9.3 ; 14.3]$ versus $13.2[11.8 ; 15.4]$ years; $P=0.01)$, but showed similar results than the whole population for all the findings. 
In our study, exacerbation which is a known factor for future risk in asthma [9] was not associated to a different frequency of significant reversibility. It may be due to the relative small population studied compared to longitudinal studies showing that a low BDR during childhood is related to poor pulmonary function from childhood into adulthood [10,11]. We did not observe any relationship between $\mathrm{FEV}_{1}$ reversibility and asthma symptom control, but there were very few children with uncontrolled asthma in our study population.

The delay since last LABA inhalation was declared, which could be a limitation, but we took great care about the schedule reported by the child and his/her parents and unreliable cases were excluded. The difference in pulmonary function in the three groups is in agreement with our assessment of the delay (Table 1).

Our results suggest that it was mainly the persistence of bronchoconstriction that influenced the occurrence of a significant reversibility independently of the delay since last LABA inhalation. The lack of reversibility under treatment might also reveal ongoing airway remodeling [12]. In contrast, the persistence of bronchoconstriction and reversibility under treatment suggests that there is still a therapeutic possibility to improve pulmonary function, especially in children taking insufficient dose of LABA.

In conclusion, baseline bronchial obstruction in children without recent exacerbation is related to a significant $\mathrm{FEV}_{1}$ reversibility. The delay since last $\mathrm{LABA}$ inhalation should not interfere in the interpretation of BDR, but the dose of LABA has to be considered. However, LABA improve baseline pulmonary function and should, therefore, not be withhold before PFT if its effect on baseline function is to be evaluated. 
Further studies looking at changes in clinical and PFT (including BDR) outcomes before and after the initiation of LABA treatment could give insight in persistent reversibility under treatment.

\section{References}

1. Graham BL, Steenbruggen I, Miller MR, Barjaktarevic IZ, Cooper BG, Hall GL, Hallstrand TS, Kaminsky DA, McCarthy K, McCormack MC, Oropez CE, Rosenfeld M, Stanojevic S, Swanney MP, Thompson BR. Standardization of Spirometry 2019 Update. An Official American Thoracic Society and European Respiratory Society Technical Statement. Am J Respir Crit Care Med 2019;200:e70-e88.

2. Chauhan BF, Chartrand C, Ni Chroinin M, Milan SJ, Ducharme FM. Addition of long-acting beta2-agonists to inhaled corticosteroids for chronic asthma in children. Cochrane Database Syst Rev 2015;CD007949.doi:10.1002/14651858.CD007949.pub2.).

3. Berger WE, Gillen M, Eckerwall G, Uryniak T, Trudo FJ, Lampl KL. Bronchodilator effect of single-dose formoterol administered by pressurized metered-dose inhaler in children with asthma aged 6 to $<12$ years receiving budesonide. Allergy Asthma Proc 2014;35:134-140.

4. Carlsen K-H, Røksund O, Olsholt K, Njå F, Leegaard J, Bratten G. Overnight protection by inhaled salmeterol on exercise-induced asthma in children. Eur Respir J. 1995;8:1852-1855.

5. Reddel HK, Taylor DR, Bateman ED, Boulet LP, Boushey HA, Busse WW, Casale TB, Chanez P, Enright PL, Gibson PG, de Jongste JC, Kerstjens HA, Lazarus SC, Levy ML, O’Byrne PM, Partridge MR, Pavord ID, Sears MR, Sterk PJ, Stoloff SW, Sullivan SD, Szefler SJ, Thomas MD, Wenzel SE, American Thoracic Society/European Respiratory Society Task Force on Asthma Control and Exacerbations. An official American Thoracic Society/European 
Respiratory Society statement: asthma control and exacerbations: standardizing endpoints for clinical asthma trials and clinical practice. Am J Respir Crit Care Med 2009;180:59-99.

6. Miller MR, Hankinson J, Brusasco V, Burgos F, Casaburi R, Coates A, Crapo R, Enright P, van der Grinten CP, Gustafsson P, Jensen R, Johnson DC, MacIntyre N, McKay R, Navajas D, Pedersen OF, Pellegrino R, Viegi G, Wanger J; ATS/ERS Task Force. Standardisation of spirometry. Eur Respir J 2005;26:319-338.

7. Quanjer PH, Stanojevic S, Cole TJ, Baur X, Hall GL, Culver BH, Enright PL, Hankinson JL, Ip MSM, Zheng J, Stocks J, ERS Global Lung Function Initiative. Multi-ethnic reference values for spirometry for the 3-95-yr age range: the global lung function 2012 equations. Eur Respir J 2012;40:1324-1343.

8. Pellegrino R, Viegi G, Brusasco V, Crapo RO, Burgos F, Casaburi R, Coates A, van der Grinten CP, Gustafsson P, Hankinson J, Jensen R, Johnson DC, MacIntyre N, McKay R, Miller MR, Navajas D, Pedersen OF, Wanger J. Interpretative strategies for lung function tests. Eur Respir J 2005;26:948-968.

9. Haselkorn T, Fish JE, Zeiger RS, Szefler SJ, Miller DP, Chipps BE Simons FER, Weiss ST, Wenzel SE, Borish L, Bleecker ER for the TENOR Study Group. Consistently very poorly controlled asthma, as defined by the impairment domain of the Expert Panel Report 3 guidelines, increases risk for future severe asthma exacerbations in The Epidemiology and Natural History of Asthma: Outcomes and Treatment Regimens (TENOR) study. J Allergy Clin Immunol. 2009;124:895-902.

10. Rasmussen F, Taylor DR, Flannery EM, Cowan JO, Greene JM, Herbison GP, Sears MR. Risk factors for airway remodeling in asthma manifested by a low postbronchodilator $\mathrm{FEV}_{1} / \mathrm{vital}$ capacity ratio: a longitudinal population study from childhood to adulthood. Am J Respir Crit Care Med 2002;165:1480-1488. 
11. McGeachie MJ, Yates KP, Zhou X, Guo F, Sternberg AL, Van Natta ML, Wise RA, Szefler SJ, Sharma S, Kho AT, Cho MH, Croteau-Chonka DC, Castaldi PJ, Jain G, Sanyal A, Zhan Y, Lajoie BR, Dekker J, Stamatoyannopoulos J, Covar RA, Zeiger RS, Adkinson NF, Williams PV, Kelly HW, Grasemann H, Vonk JM, Koppelman GH, Postma DS, Raby BA, Houston I, Lu Q, Fuhlbrigge AL, Tantisira KG, Silverman EK, Tonascia J, Weiss ST, Strunk RC. Patterns of Growth and Decline in Lung Function in Persistent Childhood Asthma. N Engl J Med 2016;374:1842-1852.

12. Goleva E, Hauk PJ, Boguniewicz J, Martin RJ, Leung DY. Airway remodeling and lack of bronchodilator response in steroid-resistant asthma. J Allergy Clin Immunol 2007;120:10651072. 
Table 1. Baseline and post-bronchodilator $\mathrm{FEV}_{1}$ and $\mathrm{FEV}_{1} / \mathrm{FVC}$, and bronchodilator response in 3 groups of children according to the delay since last LABA dose

\begin{tabular}{|c|c|c|c|c|}
\hline & $\begin{array}{c}<12 \mathrm{~h} \\
\mathrm{~N}=126\end{array}$ & $\begin{array}{c}\text { 12h to } 24 h \\
N=88\end{array}$ & $\begin{array}{l}>24 h \\
N=46\end{array}$ & $P$-value \\
\hline Baseline FVC (z-score) & $0.14[-0.47 ; 0.82]$ & $0.03[-0.69 ; 0.79]$ & $0.07[-0.49 ; 0.66]$ & \\
\hline Baseline FEV 1 (z-score) & $-0.24[-0.89 ; 0.46]$ & $-0.37[-0.92 ; 0.58]$ & $-0.55[-1.38 ; 0.10]$ & 0.08 \\
\hline Baseline FEV $\mathbf{F} / \mathbf{F V C}$ (z-score) & $-0.67[-1.53 ; 0.05]$ & $-0.84[-1.28 ; 0.32]$ & $-1.05[-1.94 ;-0.34]$ & 0.05 \\
\hline Baseline obstruction & $26(21)$ & $15(17)$ & $16(35)$ & 0.27 \\
\hline Post-BD FVC (z-score) & $0.15[-0.48 ; 0.83]$ & $-0.09[-0.62 ; 0.79]$ & $0.19[-0.44 ; 0.67]$ & \\
\hline Post-BD FEV 1 (z-score) & $0.12[-0.61 ; 0.73]$ & $0.08[-0.57 ; 0.91]$ & $-0.14[-0.53 ; 0.55]$ & 0.45 \\
\hline Post-BD FEV $1 /$ FVC (z-score) & $-0.27[-0.84 ; 0.72]$ & $0.11[-0.82 ; 0.65]$ & $-0.13[-1.01 ; 0.31]$ & 0.32 \\
\hline $\mathrm{FEV}_{1}$ reversibility $\geq 12 \% \operatorname{Pr}$ & $10(8)$ & $4(5)$ & $7(15)$ & 0.30 \\
\hline
\end{tabular}

Results are expressed in median [Q1;Q3]) or number (\%). FVC: Forced Vital Capacity; $\mathrm{FEV}_{1}$ :

Forced Expiratory Volume in $1 \mathrm{~s}$; Post-BD: post-short acting bronchodilator inhalation; Pr: predicted value 